\title{
TEACHING GRAMMAR USING PICTURES
}

\author{
Oleh: Henny Uswatun Hasanah \\ (Dosen Tetap Prodi Tadris Bahasa Inggris STAIN Pamekasan)
}

\begin{abstract}
:
Teaching is a process of communication. It has to be created through the way of teaching and exchanging the message or information by every teacher and student. The message can be knowledge, skills, ideas, experiences, and many others. Through the process of communication, the people can receive the message or information. To avoid misunderstanding in the process of communication, media are needed in the process of teaching. Using pictures can make exercises and activities more interesting and more interactive. We can constantly improve our activities by looking at what went well and what fell flat. These 5 unique ways to practice grammar using pictures are a jumping off point, and can be expanded in lots of interesting ways.
\end{abstract}

Key words:

Teaching grammar, Pictures

\section{Introduction}

Teaching as a part of teaching learning process and which is most done by a teacher has important role in education. If there is the teacher teaching, there will be a student learning. It means that the operation of education in relation to the goal in school assigned by the teaching learning process between the teacher and the learner. In other words learning and teaching are two things which cannot be a separated each other. So in teaching learning process is expected to be able to give good contribution in order that the students will not find difficulties.

Grammar teaching has often been regarded as a structure based, formal activity. After the integration of several sources and techniques, which are mainly based on communicative activities, the teaching of grammar gained a new insight. In the teaching of grammar, technique-resource combinations are often modified to structure-discourse match and if well developed, they can be used effectively for all phases of a grammar lesson. In order to make a grammar lesson effective, beneficial, and interesting a teacher should use some well-developed and fascinating techniques in the classroom. ${ }^{1}$

Teaching grammar is not something new for teachers especially for the language teachers. It already has

\footnotetext{
${ }^{1}$ http://itesli.org/Techniques/Saricoban-
}

\section{Songs.htm}


been done for many years by the teacher at the educational institutions. The teacher teaches grammar not only at the junior high school up to college, but now it is taught by the teacher from the beginning up to high level such as at the kindergarten up to college. The teacher who teaches grammar has different style, strategy, and method. It depends on the material and the student's level. ${ }^{2}$

To teach grammar the teacher might know that used by students in every day learning in the classroom activities. They have difficulty when understand about grammar because they bored study English. Therefore, a teacher may use the suitable learning with their students in the classroom. One of the grammar include as the factor that very important in English because in the writing and speaking it must be use rule that grammatically suitable. Grammar is partly the study of what forms (or structure) are possible in a language. ${ }^{3}$ Traditionally, grammar has been concerned almost exclusively with analysis at the level of sentence.

Thus grammar is a description of the rules that govern how a language's sentences are formed. Nunan stated that grammar is description of the structure of a language and the way in which linguistic unit such as words and

\footnotetext{
${ }^{2}$ Ummah, Sumihatul. 2013. Jurnal Okara Vol. 2, tahun ke VIII, November 2013: The Effective Teaching Grammar Activities With No Resources. Unit Bahasa STAIN Pamekasan, h. 47.

${ }^{3}$ Scott Thornbury, How to Teach Grammar (England:Pearson Education Limited, 1999), p. 1.
}

phrases are combined to produce sentences in the language. ${ }^{4}$ So grammar becomes fundamental element in English.

In linguistics, grammar is the set of structural rules governing the composition of clauses, phrases, and words in any given natural language. ${ }^{5}$ Grammar is the system of a language. People sometimes describe grammar as the "rules" of a language; but in fact no language has rules. If we use the word "rules", we suggest that somebody created the rules first and then spoke the language, like a new game. But languages did not start like that. Languages started by people making sounds which evolved into words, phrases and sentences. No commonlyspoken language is fixed. All languages change over time. What we call "grammar" is simply a reflection of a language at a particular time.

In teaching learning activities, the teacher need startaegy and technique which is suitable to be applied in the classroom. Strategy is a procedure used by teacher and the students which serve as way of reaching a goal as effective and efficient. ${ }^{6}$ Teacher must know the strategy or the method for the students in teaching learning activities, because before teacher teaches the students, a teacher must prepare the material and

${ }^{4}$ David Nunan, Second Language
Teaching \& Learning (Boston:Heinle\&heinle
Publisher, 1999), p. 97.
${ }^{5}$ http://en.wikipedia.org/wiki/grammar
accessed on April, 14th 2014.
${ }^{6}$ Lif Khoiru Ahmadi, Pembelajaran
Akselerasi (Jakarta: PT. Prestasi Pustaka Karya,
2011), h. 84


strategy that is suitable for the students in the classroom.

Grammar can be incredibly dry and tedious if we allow it to be, but with a little inventiveness, we can be sure that each and every time we approach a grammar lesson, we have an arsenal of engaging activities. One of the best ways to get inspired is to let pictures do the work for you. Using pictures can make exercises and activities more interesting and more interactive.

\section{Grammar}

In linguistics, grammar is the set of structural rules governing the composition of clauses, phrases, and words in any given natural language. The term refers also to the study of such rules, and this field includes morphology, syntax, and phonology, often complemented by phonetics, semantics, and pragmatics. ${ }^{7}$

"An English grammar" is a specific description, study or analysis of such rules. A reference book describing the grammar of a language is called a "reference grammar" or simply "a grammar". A fully explicit grammar that exhaustively describes the grammatical constructions of a language is called a descriptive grammar. This kind of linguistic description contrasts with linguistic prescription, an attempt to discourage or suppress some grammatical constructions, while promoting others. For example, preposition stranding occurs widely in

${ }^{7}$ http://en.wikipedia.org/wiki/Grammar
Germanic languages and has a long history in English.

Grammar is the system of a language. People sometimes describe grammar as the "rules" of a language; but in fact no language has rules*. If we use the word "rules", we suggest that somebody created the rules first and then spoke the language, like a new game. But languages did not start like that. Languages started by people making sounds which evolved into words, phrases and sentences. No commonly-spoken language is fixed. All languages change over time. What we call "grammar" is simply a reflection of a language at a particular time.

Do we need to study grammar to learn a language? The short answer is "no". Very many people in the world speak their own, native language without having studied its grammar. Children start to speak before they even know the word "grammar". But if you are serious about learning a foreign language, the long answer is "yes, grammar can help you to learn a language more quickly and more efficiently." It's important to think of grammar as something that can help you, like a friend. When you understand the grammar (or system) of a language, you can understand many things yourself, without having to ask a teacher or look in a book.

So think of grammar as something good, something positive, something that you can use to find your way - like a signpost or a map. ${ }^{8}$ hat.htm 
Grammar is partly the study of what forms (or structures) are possible in a language. Traditionally, grammar has been concerned almost exclusively with analysis at the level of the sentence. Thus a grammar is a description of the rules that govern how a language's sentences are formed. ${ }^{9}$

Grammar is a process for making a speaker's or writer's meaning clear when contextual information is lacking. ${ }^{10}$

Based on definition above, it can be concluded that grammar as a description of the rules for forming sentences, including an account of the meanings that these forms convey and said also that grammar adds meanings that are not easily inferable from the immediate context.

\section{Teaching Grammar}

Grammar is central to the teaching and learning of languages. It is also one of the more difficult aspects of language to teach well.

Many people, including language teachers, hear the word "grammar" and think of a fixed set of word forms and rules of usage. They associate "good" grammar with the prestige forms of the language, such as those used in writing and in formal oral presentations, and "bad" or "no" grammar with the language used in everyday conversation or used by speakers of nonprestige forms.

\footnotetext{
${ }^{9}$ Scott Thornbury, How to Teach Grammar (England:Pearson Education Limited, 1999), p. 1

${ }^{10}$ lbid., p. 4
}

Language teachers who adopt this definition focus on grammar as a set of forms and rules. They teach grammar by explaining the forms and rules and then drilling students on them. This results in bored, disaffected students who can produce correct forms on exercises and tests, but consistently make errors when they try to use the language in context.

Other language teachers, influenced by recent theoretical work on the difference between language learning and language acquisition, tend not to teach grammar at all. Believing that children acquire their first language without overt grammar instruction, they expect students to learn their second language the same way. They assume that students will absorb grammar rules as they hear, read, and use the language in communication activities. This approach does not allow students to use one of the major tools they have as learners: their active understanding of what grammar is and how it works in the language they already know.

The communicative competence model balances these extremes. The model recognizes that overt grammar instruction helps students acquire the language more efficiently, but it incorporates grammar teaching and learning into the larger context of teaching students to use the language. Instructors using this model teach students the grammar they need to know to accomplish defined communication tasks. 
The aim of teaching grammar is to help the students to write correctly, to help the students use it more effectively, to help them learn a foreign language and give them knowledge about the way language works. There are some key concepts and the language teaching classroom in teaching grammar, namely: ${ }^{11}$

a. Grammar rule describes the away that language works, but language changes over times so grammar rules are not fixed.

b. The teacher need to keep up to date with what parts of the language are changing and how.

c. Grammar rules traditionally describes written language rather than spoken language. For example, repetition, exclamation, and contraction.

d. Very often speakers of a language can speak and write it well without consciously knowing any grammatical rules of terms.

e. Learning some grammatical rules and terms makes language learning easier for some learners.

f. Just learning grammatical rules and structures don't give learners enough help with learning how to communicate, which is the main purpose of language.

\footnotetext{
${ }^{11}$ Abdul Muhyi Romadhon, The Implementation of GTM on English Grammar Teaching at the Intensive Class of Latansa BEC Pamekasan, (Pamekasan: STAIN Pamekasan Press, 2013), p. 9.
}

\section{Definition of Media}

Teaching is a process of communication. It has to be created through the way of teaching and exchanging the message or information by every teacher and student. The message can be knowledge, skills, ideas, experiences, and many others. Through the process of communication, the people can receive the message or information. To avoid misunderstanding in the process of communication, media are needed in the process of teaching.

Media is means of sending message from sender to message receive. According to Gagne in Arief media $^{12}$ is kinds of components that can stimulate the students to study in learning process. In addition, Brown defines media $^{13}$ as the tools or the physical thing used by a teacher to facilitate the instruction (online, access on 20 October 2011).

From the definitions above, the writer makes a conclusion that media is kinds of components, tools, materials, or events that establish conditions used by a teacher to stimulate the students to acquire knowledge, skill and attitudes, and engage the learners in learning process.

\section{Function of Media}

Media has very advantages for many aspects in our life especially in

\footnotetext{
${ }^{12}$ Sadiman, Arief. 1990. Media Pendidikan. Pustekkom Dikbud dan C.V. Rajawali, p. 6.

${ }^{13}$ Brown, H Douglas. 2007. Principle of Language Learning and Teaching. USA: Longman.
} 
learning process. Suyanto in Megawati, stated that the function of media in teaching learning process are ${ }^{14}$ :

1. Media can save our time as a teacher

2. Media can stimulate interest to learn

3. Media can encourage student's participation

4. Media can provide a review

5. Media can help the students learn communicate ideas visually

6. Media can provide medium for individual or group report

7. Media can make a classroom dynamic, relevant and attractive.

Besides that, according to Sadiman, also stated that the function of media in teaching learning process is ${ }^{15}$ :

a. Aids to Instruction

Media gives serve to help teacher and instructors to manage the instruction more efficiently especially in learning process. It means, media helps teachers to communicate more effectively and take over the operating role of instruction from teacher and instructors.

b. Aids to Learning

Media gives serve to help students learn more efficiently. Media promote understanding, assist in the transfer of training and assist in assignments.

From kinds function of media above, the writer concludes that media is really important in teaching learning

\footnotetext{
${ }^{14}$ Suyanto, Kasihani K.E. 2007. English for Young Learner. Jakarta: Bumi Aksara. P.10

${ }^{15}$ Sadiman, Arief. 1990. Media Pendidikan. Pustekkom Dikbud dan C.V. Rajawali, p. 7.
}

process especially for the teachers and the students.

\section{Roles of Media in a Teaching- Learning process}

The use of media in a teachinglearning process is very important. Locatis and Atkinson give a brief explanation on the roles of media or instructional media as follows:

1. To entertain

Media can be used as recreation and enjoyment. It includes fictional stories and poem published in books and magazines; records; tapes and radio broadcast of music, music typically shown in motion pictures theaters; and comedies ,dramas, and sporting events in television.

2. To Inform

The use of media can increase awareness or present facts. It includes newspapers, documentaries on radio and television, and advertisements in all media.

3. To instruct

Media are used to take the viewer and listener from state of not knowing to one of knowing. From a state of poor performance to a state of competence. It includes motion pictures, slides, and film strips records and audiotapes (online, accessed on August, 20 2012)

\section{What are pictures?}

A picture is simply a photo of something or someone on a piece of card, paper, etc, ect. A picture can sometimes be something to treasure 
memories or simply just a decortion. A picture can be in books and frames wich you can look at whenever you would like. ${ }^{16}$

A picture description is an ideal way of practicing your English vocabulary in all sorts of fields. Pictures provide serious language practice and can be invaluable in the classroom for stimulating discussion and bringing enormous variety to lessons. They also provide the teacher with a flexible and convienient tool to test many different things in exams. ${ }^{17}$

There are two guidelines for describing pictures: ${ }^{18}$

\begin{tabular}{|c|c|}
\hline Do & Don't \\
\hline $\begin{array}{l}\text { Look carefully } \\
\text { at the photos. } \\
\text { Think how to } \\
\text { describe what } \\
\text { you can see. } \\
\text { Take your time } \\
\text { to do it. } \\
\text { Be as precise } \\
\text { as you can } \\
\text { when you } \\
\text { describe the } \\
\text { photo it self. } \\
\text { Use some } \\
\text { 'position' } \\
\text { language if it } \\
\text { helps. } \\
\text { Use present } \\
\text { continuous } \\
\text { verbs to }\end{array}$ & $\begin{array}{l}\text { Don't worry if } \\
\text { you don't } \\
\text { understand } \\
\text { immediately } \\
\text { what is going on } \\
\text { in the picture. } \\
\text { Don't worry if } \\
\text { you don't know } \\
\text { the precise } \\
\text { words for what } \\
\text { you can see; use } \\
\text { alternatives. } \\
\text { Don't use } \\
\text { general } \\
\text { language to } \\
\text { describe people. } \\
\text { You should use } \\
\text { vocabulary of }\end{array}$ \\
\hline
\end{tabular}

\footnotetext{
${ }^{16} \mathrm{http}: / / \mathrm{www}$. answers.com/Q/What_are_ pictures

${ }^{17}$ M. Cristina C.B. Picture Description. Guidelines, Techniques \& Exam Tips. p. 1

${ }^{18}$ Ibid., p. 3
}

\begin{tabular}{|c|c|c|}
\hline$>$ & $\begin{array}{l}\text { describe what is } \\
\text { happening. } \\
\text { If there is a } \\
\text { person on } \\
\text { people on the } \\
\text { photo, you will } \\
\text { need to } \\
\text { describe their } \\
\text { appearance. } \\
\text { Answer } \\
\text { questions as } \\
\text { fully as } \\
\text { possible. Keep } \\
\text { talking, give } \\
\text { details, explain } \\
\text { your point, ask } \\
\text { questions, } \\
\text { paraphrase, } \\
\text { don't get stuck } \\
\text { on words,,.. Any } \\
\text { device that you } \\
\text { can carry a } \\
\text { topic through } \\
\text { will help your } \\
\text { performance. } \\
\text { Try to direct the } \\
\text { conversations } \\
\text { towards } \\
\text { something you } \\
\text { are interested in } \\
\text { and can talk } \\
\text { about easily. } \\
\text { Speak naturally } \\
\text { and be } \\
\text { animated! Keep } \\
\text { eye contact with } \\
\text { the examiner, } \\
\text { be friendly and } \\
\text { show a positive } \\
\text { attitude. }\end{array}$ & $\begin{array}{l}\text { the level } \\
\text { required. } \\
\text { Don't give to } \\
\text { many one-or } \\
\text { two-words } \\
\text { answer.avoid } \\
\text { answer which } \\
\text { are single words } \\
\text { or lists. Silence } \\
\text { is you enemy!if } \\
\text { you are not a } \\
\text { talkative person } \\
\text { by nature,you } \\
\text { must make an } \\
\text { extra effort for } \\
\text { the test. } \\
\text { Don't feel you } \\
\text { have to stick } \\
\text { rigidly to the } \\
\text { subject. Don't } \\
\text { give complicated } \\
\text { explanations if } \\
\text { you are not sure. } \\
\text { Don't be shy! } \\
\text { This is your } \\
\text { chance to show } \\
\text { how well you } \\
\text { can speak. } \\
\text { Smile and relax! }\end{array}$ \\
\hline
\end{tabular}




\section{Teaching Grammar Using Pictures}

As the teachers we know there are always going to be topics that are challenging to make fun or interactive.

Grammar can be incredibly dry and tedious if we allow it to be, but with a little inventiveness, we can be sure that each and every time we approach a grammar lesson, we have an arsenal of engaging activities.

One of the best ways to get inspired is to let pictures do the work for you. These 5 unique ways to practice grammar using pictures will serve you indefinitely because you can adapt them, recycle them and make them your own in many different ways.

The first thing you need to do immediately is get your hands on a stack of twenty to thirty magazines. Some of the best choices are those that use thick paper, vivid images, and approach a variety of topics. Magazines like: $O$, National Geographic, Martha Stewart Living, Cosmo, Glamour, etc. will serve you really well. Take some time and compile all different categories of pictures including: famous people, people doing things, pictures of the home, street scenes, animals, food, rooms in the home, odd cartoons, diverse people and groups of people, interesting and colorful objects, etc. I recommend gluing them to construction paper and laminating them if you have the option. You will get years of use of them and continue to add to them as time goes on.

\section{People Pictures}

People pictures should be number one on your list as you will use them the most for activities. There are so many ways you can use people pictures, there is no way to list them all. Here are some ideas to get you started. 20 questions with famous people (is it a man? is he a singer?); describing people using picture; what are they doing; What happened or what is happening? Create a story from the picture; write the sequence of a story for the picture and share.

There are numerous ways you can utilize pictures of people in the ESL classroom. Try out different activities with different levels to create your toolbox of go-to exercises.

2. Creating Captions

You can also do a lot with cartoons, news pictures, or oddlythemed pictures. Have the students write their own captions to create a punch line. You can utilize news stories or current events and have them write short captions that tell what is happening in the picture using a reporter tone. I have even used Calvin and Hobbs by whiting out all the dialogue and ask students to fill in their own dialogue and/or captions. You can give them perimeters or you can leave it wide open. Think beyond what is happening in this picture. Challenge their critical thinking skills and creativity for powerful results.

\section{Cut-Up Stories}

Cut-up stories can be a lot of fun with pictures. You can practice things like sequence, directions, story-telling, 
and various tenses with cut-up stories. Essentially it is a puzzle made of photographs. Have a stack of 8-10 photographs that are related so that they can be put in some kind of order (sequence, what happened, solve a crime, etc.). Put the students in small groups and have them examine the pictures. Tell them what the goal is. For example, tell a story by putting these 7 pictures into an order. Give the people names and don't just tell me the obvious, use your imagination and create a fictional story. For a lower level, it could be something like this: there are 10 pictures in your envelope. Each envelope shows a different activity being done and you need to put them order and describe each of the steps. Examples could be making a cup of tea, making a sandwich, how to take the bus, etc. What you choose will be based on what topic(s) you would like them to practice.

\section{Partial Pictures}

This is a fun picture activity that can be approached for low intermediate or above. You can use more abstract pictures or artwork for this activity. Take a variety of photographs that are $8 \times 10$ or larger and paste them on either construction paper or cardboard. You will then want to cover up most of the picture using squares of paper.

I tend to do this on the board with magnets, but you could also use doublesided tape. You'll want to be able to pull off each square easily. This is essentially a guessing game where they should be asking a lot of questions. You want them to determine what the picture or piece of artwork is with only a limited peek at the photograph. If students don't have any guess, reveal a little more and have them ask more questions. Continue until the entire picture is revealed or someone answers. You can vary this activity by doing it in smaller groups and by applying it to different language lessons.

\section{Picture Dictation}

This activity is often a favorite of students. It is Pictionary on steroids and much more challenging. The best grammar activities to use this for are: there is/there are, prepositions of place or direction combined with house vocabulary, or what is happening in the picture. Put the students into pairs and give each student a picture, face down. Tell them to take a turn describing their picture to their partner with several sentences and descriptions. The partner has to draw what their partner tells them. For example, their partner says, "This is a picture of a kitchen. In the kitchen on the right hand side there is a big refrigerator. Next to the fridge there is a long cabinet. On top of the cabinet there is a vase with flowers. "You'll want to monitor how much concrete information they are giving and let the partner know that they can ask clarifying questions. After a few minutes have them switch. At the end of the activity, you can debrief as a class by looking at the original picture and comparing it the one that was drawn. It is a terrific activity to combine lots of listening and speaking skills along with comprehension of vocabulary and grammar. 


\section{Conclusion}

Teaching grammar has been compared to other fun things - like using pictures.

Teaching the yearly grammar unit can be like giving a child cough medicine. Some students take it without flinching; others -- those with a mental block about grammar -- flinch at the mere mention of the word. Teaching grammar has to be one of toughest tasks a teacher faces, but we all know that grammar skills are essential to students' success on standardized tests and college entrance exams, in their ability to communicate orally and in writing, and in life! So the more fun we can have with grammar -- and the more varied approaches we can use to teach it -- the more likely our students are to 'get it.'

Using pictures can make exercises and activities more interesting and more interactive.

We can constantly improve our activities by looking at what went well and what fell flat. These 5 unique ways to practice grammar using pictures are a jumping off point, and can be expanded in lots of interesting ways.

\section{BIBLIOGRAPHY}

Abdul Muhyi Romadhon, The Implementation of GTM on English Grammar Teaching at the Intensive Class of Latansa BEC Pamekasan, (Pamekasan: STAIN Pamekasan Press, 2013).

Brown, H Douglas. 2007. Principle of Language Learning and Teaching. USA: Longman.
David Nunan, Second Language Teaching \& Learning (Boston: Heinle \& heinle Publisher, 1999)

http://iteslj.org/Techniques/SaricobanSongs.html

http://en.wikipedia.org/wiki/grammar accessed on April, 14th 2014.

http://en.wikipedia.org/wiki/Grammar

https://www.englishclub.com/grammar/w hat.htm

http://www.answers.com/Q/What_are_pi ctures

Lif Khoiru Ahmadi, Pembelajaran Akselerasi (Jakarta: PT. Prestasi Pustaka Karya, 2011).

M. Cristina C.B. Picture Description. Guidelines, Techniques \& Exam Tips.

Sadiman, Arief. 1990. Media Pendidikan. Pustekkom Dikbud dan C.V. Rajawali

Scott Thornbury, How to Teach Grammar (England:Pearson Education Limited, 1999).

Suyanto, Kasihani K.E. 2007. English for Young Learner. Jakarta: Bumi Aksara

Ummah, Sumihatul. 2013. Jurnal Okara Vol. 2, tahun ke VIII, November 2013: The Effective Teaching Grammar Activities With No Resources. Unit Bahasa STAIN Pamekasan. 